\title{
Postmortem assessment of chronic airways obstruction by tantalum bronchography
}

\author{
$K$. W. M. SCOT T a nd G.M.STEINER \\ Academic Division of Pathology, University of Sheffield and Department of Radiology, \\ Royal Hospital, Sheffield
}

\begin{abstract}
Scott, K. W. M. and Steiner, G. M. Thorax, 30, 405-414. Postmortem assessment of chronic airways obstruction by tantalum bronchography. Tantalum bronchography was performed on 22 left lungs obtained at necropsy. Seven were from patients dying in cor pulmonale as a result of chronic airways obstruction and 15 were from unselected necropsies. Of the latter group, nine had no evidence of respiratory disease and six had pathological changes of emphysema and bronchial mucous gland enlargement when the lungs were examined following formalin fixation.

A range of changes in the bronchographic appearances from the normal to the grossly abnormal is illustrated. The main changes in severely diseased lungs were: irregularity of the bronchial walls, failure of the walls to taper towards the periphery, areas of narrowing and dilatation, and 'pooling' of tantalum at the ends of airways.

A count was made of the numbers of small airway branches in the most distal $4 \mathrm{~cm}$ of the lung and also of the number of airways of less than $1 \mathrm{~mm}$ in diameter. Patients dying in cor pulmonale had a significantly reduced total number of patent small airways in the area measured and also fewer patent airways of less than $1 \mathrm{~mm}$ diameter compared to both the other groups.

Histological study of four of the lungs in greater detail revealed that the reduction in small airways filling was the result of a combination of obliteration and obstruction of the lumen by pus. Tantalum bronchography provides a good indication of the state of the bronchial tree at the time of death, and the changes seen are the result of both acute and chronic disease processes.
\end{abstract}

The site of obstruction in chronic obstructive airways diseases has been variously located by different observers. Gandevia (1963), Fraser and Paré (1970), and Macklem, Fraser, and Brown (1965) demonstrated excessive changes in the lumen of the larger airways of chronic bronchitics on respiration and even complete occlusion on coughing. They therefore placed the site of obstruction in the larger airways.

More recently, Hogg, Macklem, and Thurlbeck (1968) have investigated the pressure relationships in the airways by using wedged intrabronchial catheters. They have demonstrated that in the normal lung the central larger airways provide about $75 \%$ of the airway resistance and the peripheral airways ( $2 \mathrm{~mm}$ or less) the other $25 \%$. However, in patients dying of chronic airways obstruction the increase in total resistance to air flow was provided by an increase in the resist- ance of the smaller passages. The histology of these airways showed areas of mucous plugging, oedema, inflammation, and fibrosis.

Tantalum bronchography allows the radiographic investigation of the smallest airways down to respiratory bronchiole level (Gamsu et al., 1971; Nadel, Wolfe, and Graf, 1968). It was decided to carry out this investigation on the lungs of patients dying of cor pulmonale as a result of chronic airways obstruction and of controls in order to assess the qualitative and, if possible, the quantitative changes in the peripheral airways.

\section{MATERIAL AND METHODS}

The investigation was carried out on left lungs obtained at necropsy from three groups of patients. Group 1 consisted of nine patients who 
had no clinical history of cough, sputum production or breathlessness and who did not die from respiratory disease. Group 2 consisted of seven patients dying in cor pulmonale with clinical evidence of heart failure and airways obstruction. The clinical findings in this group are shown in Table I along with the results of respiratory and cardiac investigations. They all had long histories of sputum production and breathlessness. Five out of the seven were oedematous and all had hypoxia and hypercapnia as shown by the arterial blood gases performed on admission during the final exacerbation of the disease. They also had severe impairment of ventilation function as shown by the results of forced expiratory volume $\left(\mathrm{FEV}_{1}\right)$ and forced vital capacity $(\mathrm{FVC})$. These tests were performed during a quiescent phase before the terminal admission. Group 3 consisted of six patients who had a history of cough and sputum production, and in four of these a diagnosis of chronic bronchitis had been made. They had never complained of breathlessness, were not oedematous, and had not had respiratory investigations. They all died from conditions other than airways obstruction.

Tantalum remains suspended in air for only a very short distance and forms an explosive mixture with oxygen. Accordingly it has to be released near the point of interest using a catheter and has to be suspended in air or fluid.

The bronchial tree was first sucked as clean as possible and then attempts were made to wedge the catheter into a bronchus in the upper, middle, and lower zones of the lung. Several tantalum insufflations were made at each site, using a hand pump, to ensure maximal possible filling of the airways. After the insufflation the lung was suspended in a pressure chamber and inflated to a negative pressure of $20-30 \mathrm{mmHg}$.
Radiographs were taken in two planes when th lung was fully inflated to a steady state, using क्षे vertical and horizontal beam, on Kodak Crystalle fine grain film. Focus film distance was $200 \mathrm{~cm}$, Kvp 35, Mas 1200-1600. Focal spot size waథิ nominally $0.8 \mathrm{~mm}$ but was effectively $1.6 \mathrm{~mm}$.

The following qualitative assessments were made of the bronchograms: the regularity of the bifurcations; the regularity and smoothness of the bronchial walls; the presence of dilatations anffy strictures of the bronchial walls; and the presencet of cystic spaces.

A quantitative assessment of the most perp pheral $4 \mathrm{~cm}$ of airways outlined was made b. counting the number of branches and measuring their diameter using a calibrated magnifying glass.

The lungs were then inflated with $10 \%$ formol saline, introduced by a catheter in the left mai bronchus, until the pleural surface was smoothe Following fixation in this state samples of the bronchial tree were taken from three sites: (禺 the left main bronchus just proximal to its bifurcation; (2) the bronchus to the basal sege ments (the bronchus immediately below the origie of the bronchus to the apical segment of th: lower lobe); and (3) the bronchus to the inferiog segment of the lingula $5 \mathrm{~mm}$ beyond its origi (Restrepo and Heard, 1963). Transverse blocks were embedded in paraffin and stained by haemas toxylin and eosin and periodic acid Schiff, follow ing which they were projected at a magnification of 20 diameters on to a point-counting grid (the points were at the angles of equilateral triangles of side $0.6 \mathrm{~cm}$ ) (Dunnill, Massarella, and Anden son, 1969). The number of points falling of bronchial mucous glands was expressed as a pep. centage of the total number of points and a meas was taken of the values for each of the three

T A B L E I

CLINICAL DETAILS OF 7 PATIENTS WITH COR PULMONALE

\begin{tabular}{|c|c|c|c|c|c|c|c|c|c|}
\hline Case No. & $\begin{array}{c}\text { Daily Sputum } \\
\text { for } 3 / 12 \text { or } \\
\text { more }\end{array}$ & $\begin{array}{c}\text { Breathlessness } \\
\text { Grade }\end{array}$ & $\begin{array}{c}\text { History of } \\
\text { Chest Disease } \\
\text { (years) }\end{array}$ & Oedema & ECG & $\begin{array}{l}\mathrm{PaO}_{2} \\
(\mathrm{kPa})\end{array}$ & $\begin{array}{l}\mathrm{PaCO}_{2} \\
(\mathrm{kPa})\end{array}$ & $\begin{array}{c}\text { FEV } \\
\text { (I) }\end{array}$ & $\begin{array}{c}\text { FVC } \\
\text { (1) }\end{array}$ \\
\hline $\begin{array}{r}1 \\
4 \\
7 \\
10 \\
11 \\
12 \\
13\end{array}$ & $\begin{array}{l}+ \\
+ \\
+ \\
+ \\
+ \\
+\end{array}$ & $\begin{array}{l}5 \\
3 \\
5 \\
4 \\
5 \\
4\end{array}$ & $\begin{array}{l}20+ \\
20 \\
10+ \\
15+ \\
20 \\
10+ \\
18\end{array}$ & $\begin{array}{l}\text { Nil } \\
\text { Moderate } \\
\text { Moderate } \\
\text { Moderate } \\
\text { Moderate } \\
\text { Nil } \\
\text { Mild }\end{array}$ & $\begin{array}{l}\text { RVH 'p' pulm } \\
\text { RVH 'p' pulm } \\
\text { RVH 'p' pulm } \\
\text { RVH ‘p' pulm } \\
\text { NAD } \\
\text { RVH 'p' pulm } \\
\text { 'p' pulm }\end{array}$ & $\begin{array}{l}5 \cdot 1 \\
5 \cdot 1 \\
3 \cdot 5 \\
4 \cdot 0 \\
4 \cdot 0 \\
4 \cdot 8 \\
6 \cdot 0\end{array}$ & $\begin{array}{c}13 \cdot 0 \\
8 \cdot 1 \\
9 \cdot 0 \\
8 \cdot 8 \\
11 \cdot 7 \\
6 \cdot 0 \\
7 \cdot 8\end{array}$ & $\begin{array}{l}0 \cdot 3 \\
0 \cdot 7 \\
0 \cdot 5 \\
0 \cdot 5 \\
0 \cdot 6 \\
0 \cdot 3 \\
0 \cdot 3\end{array}$ & $\begin{array}{l}1 \cdot 4 \\
2 \cdot 0 \\
2 \cdot 1 \\
1 \cdot 8 \\
1 \cdot 8 \\
1 \cdot 6 \\
1 \cdot 5\end{array}$ \\
\hline
\end{tabular}

Breathlessness grade: 1 normal; 2 hurrying on level or walking up slight incline; 3 own pace on the level; 4 stops on the level; 5 washing and dressing.

Oedema grade: mild-ankle only; moderate-legs and sacrum; gross-legs with ascites and/or pleural effusion.

Electrocardiogram (ECG): ‘p' pulm $>2 \mathrm{~mm}$ in S2; $R$ VH = right venticular hypertophy-dominant $\mathrm{R}$ on VI to V3, inverted T VI to V3, domina@̆ $R$ in aVR, and dominant $\mathbf{S}$ in V5.

$\mathrm{FEV}_{1}=$ forced expiratory volume in one second.

FVC $=$ forced vital capacity. 
sites. The lung was then sliced in the parasagittal plane at $1 \mathrm{~cm}$ intervals, and following barium sulphate impregnation (Heard, 1958) three or four slices of lung were examined to determine the amount and type of emphysema present. This was done using a plastic grid and a point-counting technique (Dunnill, 1962). The number of points falling on emphysematous areas was expressed as a percentage of the total point count of each slice and a mean was calculated for the three or four slices counted.

Using a stratified random sampling technique (Dunnill, 1968), 20 blocks were selected from each lung, embedded in paraffin, and stained by haematoxylin and eosin. These were examined for evidence of acute inflammatory changes in the bronchi and bronchioles.

Four of the cases were examined in greater detail histologically to determine the degree of airway filling by tantalum. A segment of lung, which appeared to be well filled radiologically, was excised, and multiple sections were taken to include all the airways in the distribution of the bronchus catheterized from the site of the catheter tip to the pleura. The number of airways lined or filled with tantalum was expressed as a percentage of the total number of airways present in all the sections.

The hearts were fixed, following examination of the coronary arteries, in $10 \%$ formol saline for 72-96 hours. They were then dissected, according to the method of Fulton, Hutchinson, and Morgan Jones (1952), and the right and left ventricles were weighed separately.

\section{RESULTS}

Of the four cases examined to determine the extent of filling of the airways, the two with no respiratory disease showed a high degree of success. In case 8,36 out of $43(88 \%)$ airways were lined by tantalum and in case 14, 76 out of 84 $(90 \%)$ were similarly lined. Figure 1 shows a bronchiole of approximately $0.5 \mathrm{~mm}$ in diameter which has been adequately filled with tantalum. The two cases dying in cor pulmonale showed a lower degree of filling. Case 11 had 54 out of 79 airways lined $(68 \%)$, and case 12,23 out of 63 $(37 \%)$. These patients died from an acute suppurative bronchitis and the airways which were not lined by tantalum were noted to contain a purulent exudate in the lumen. On occasion a

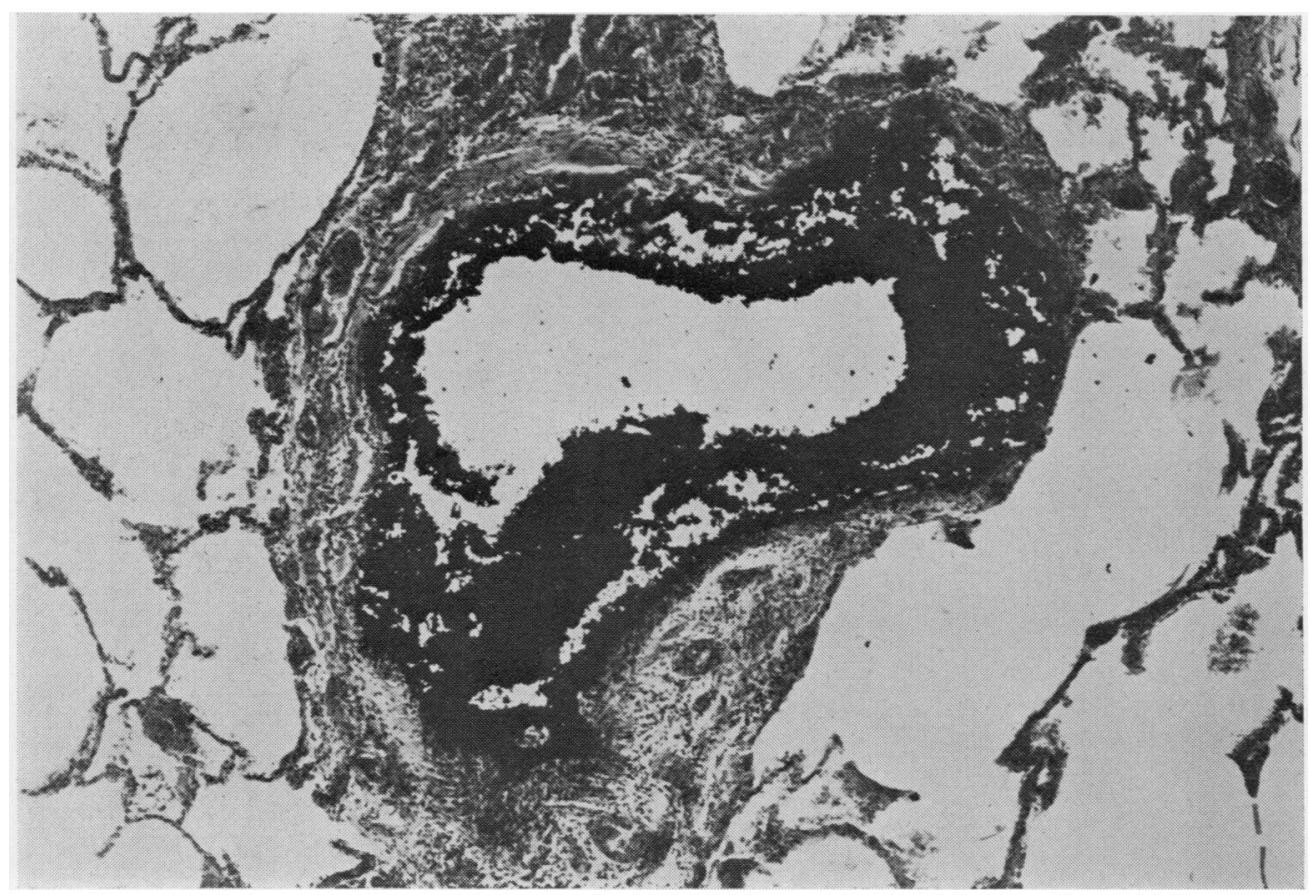

FIG. 1. Case 14. A bronchiole, approximately $0.5 \mathrm{~mm}$ diameter, filled with tantalum dust (Haematoxylin and eosin $\times 3 \cdot 75$ ). 
'false' lumen lined by tantalum was observed in the centre of a pus-filled airway. An example of this is shown (Fig. 2).

The qualitative changes associated with chronic airways obstruction are best appreciated in illustration. Figure 3 shows a radiograph of an entire left lung which had tantalum insufflated into six segmental bronchi. The airways are delineated right out to the pleura in all regions. This is a lung from a patient with no clinical or pathological evidence of respiratory disease. A higher power view of the peripheral airways, from the same case, is shown in Figure 4. The bronchial walls are smooth and taper gradually towards the periphery. Regular branching of the airways is also present. Figure 5 illustrates the peripheral branches in a patient with pathological changes of chronic bronchitis and emphysema but who did not die from respiratory disease. The walls of the bronchi are slightly irregular throughout with more marked areas of constriction and dilatation in some places. The number of branches is slightly reduced but there is still filling of the smallest airways and alveolar space. Several pools of tantalum can be seen at the ends of airways. These have a similar appearance to the 'pools' illustrated by Leopold and Gough (1963) which they considered to be areas of centrilobula emphysema. Figure 6 shows the severest changeso that were found. This is from a patient dying of cor pulmonale due to chronic airways obstruc tion. There is marked irregularity of the walls $\widehat{\Phi}$ and a lack of tapering is also seen. The number of branches is greatly reduced and this involves all the smallest branches of the bronchial tree. $\vec{O}$

Using the criteria described, it was possible to place each lung into one of three broad groups $\omega$ normal and moderately or severely diseased. This was an arbitrary division as the changes ranged in a gradual progression from normal to the mos $P$ severe grade. It was also noted that the changes were not uniform throughout the lung. One areas could show moderate changes while anothes might be more severe.

The numbers of airway branches which weres counted in the peripheral $4 \mathrm{~cm}$ of the radiograph are shown in Tables II, III, and IV and also the number of branches of diameter less than $1 \mathrm{~mm}_{-}^{-}$ The mean number of branches, in the area measured, in group 1 (no respiratory disease) was 37.4 as compared to a mean of 15.1 in group 8 (dying of cor pulmonade). This is a significan difference of means $(t=4.46 ; \mathrm{P}<0.001)$. The mearo number of branches in group 3 (non-fatal respiraø

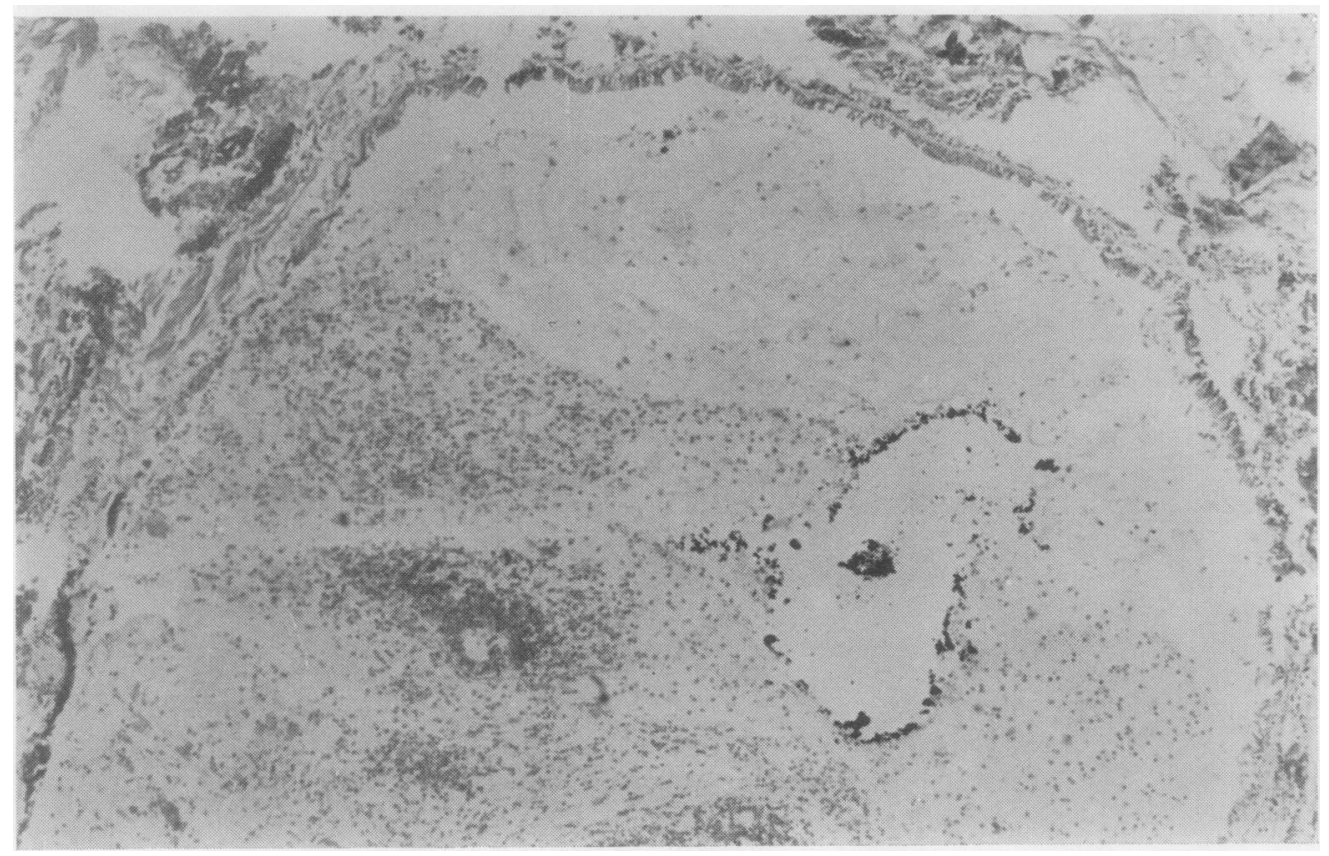

FIG. 2. Case 1. A bronchiole, $2 \mathrm{~mm}$ diameter, filled with pus showing a small lumen, $0 \cdot 3 \mathrm{~mm}$ diameter, lined with tantalum (Haematoxylin and eosin $\times 3.75$ ). 


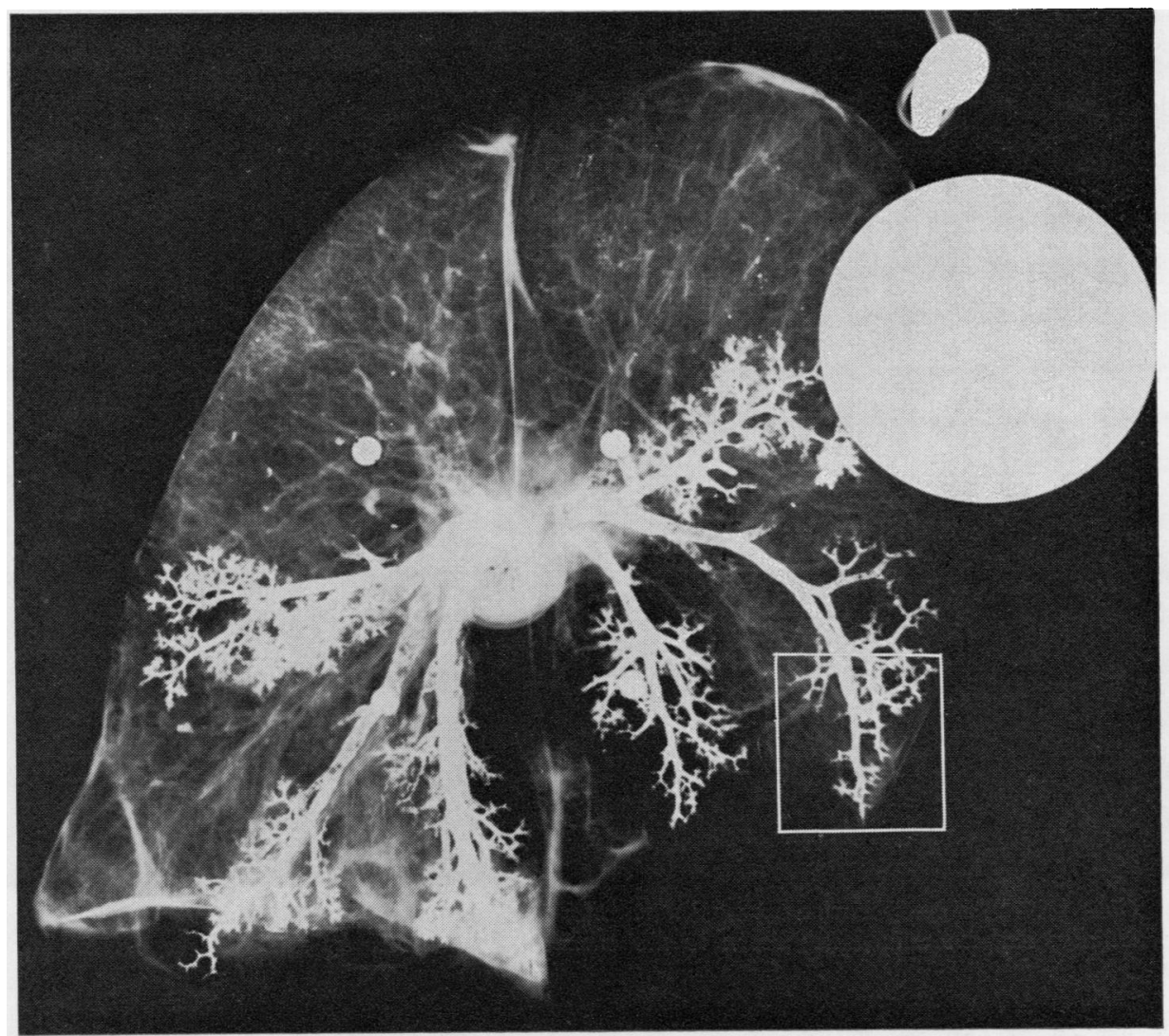

FIG. 3. Case 19. Tantalum bronchogram of a normal left lung (approximately half the actual size). The area within the box is shown in greater detail in Fig. 4.

tory disease) was $32 \cdot 3$. This is not significantly different from the mean of group $1(37 \cdot 4)(t=$ $0.662 ; P=0.50)$. Similar results were obtained on comparing the number of airway branches, of less than $1 \mathrm{~mm}$ diameter, in the three groups. The mean number of branches, of this size, in group 1 was 30.5 as compared to 10.8 in group 2 . This is a significant difference of means $(t=4 \cdot 17 ; \mathrm{P}=$ 0.001 ). There was no significant difference between the mean of group $3(28 \cdot 16)$ and the mean number of small branches in group $1(30.5)(t=0.425$; $P=0.70$ ). The mean amount of emphysema in the seven patients dying in cor pulmonale (group 2) was $43.9 \%$. This was not significantly different from the mean amount in group $3(24.6 \%)$ $(t=1.94 ; 0.10>\mathrm{P}>0.05)$. The mean bronchial mucous gland size in group 2 was $17.8 \%$ as compared to $16.8 \%$ in group 3 . This is not a significant difference of means $(t=0.35$; $0.80>\mathrm{P}>0.70$ ). Acute suppurative bronchitis was commoner in the cor pulmonale group, being present in all seven patients, than in the group not dying from respiratory disease (3 out of 6 patients).

\section{DISCUSSION}

The most significant finding of this investigation is that patients dying in cor pulmonale as a result of chronic airways obstruction have significantly fewer patent peripheral airways of approximately $1 \mathrm{~mm}$ diameter, or less, than patients dying of non-respiratory causes. This latter group included patients with no evidence of chest disease and a group with pathological evidence of chronic bronchitis and emphysema to a degree which was not significantly different from the patients dying in cor pulmonale. Both chronic bronchitis and emphysema are common diseases in the general population. The clinical incidence of chronic 


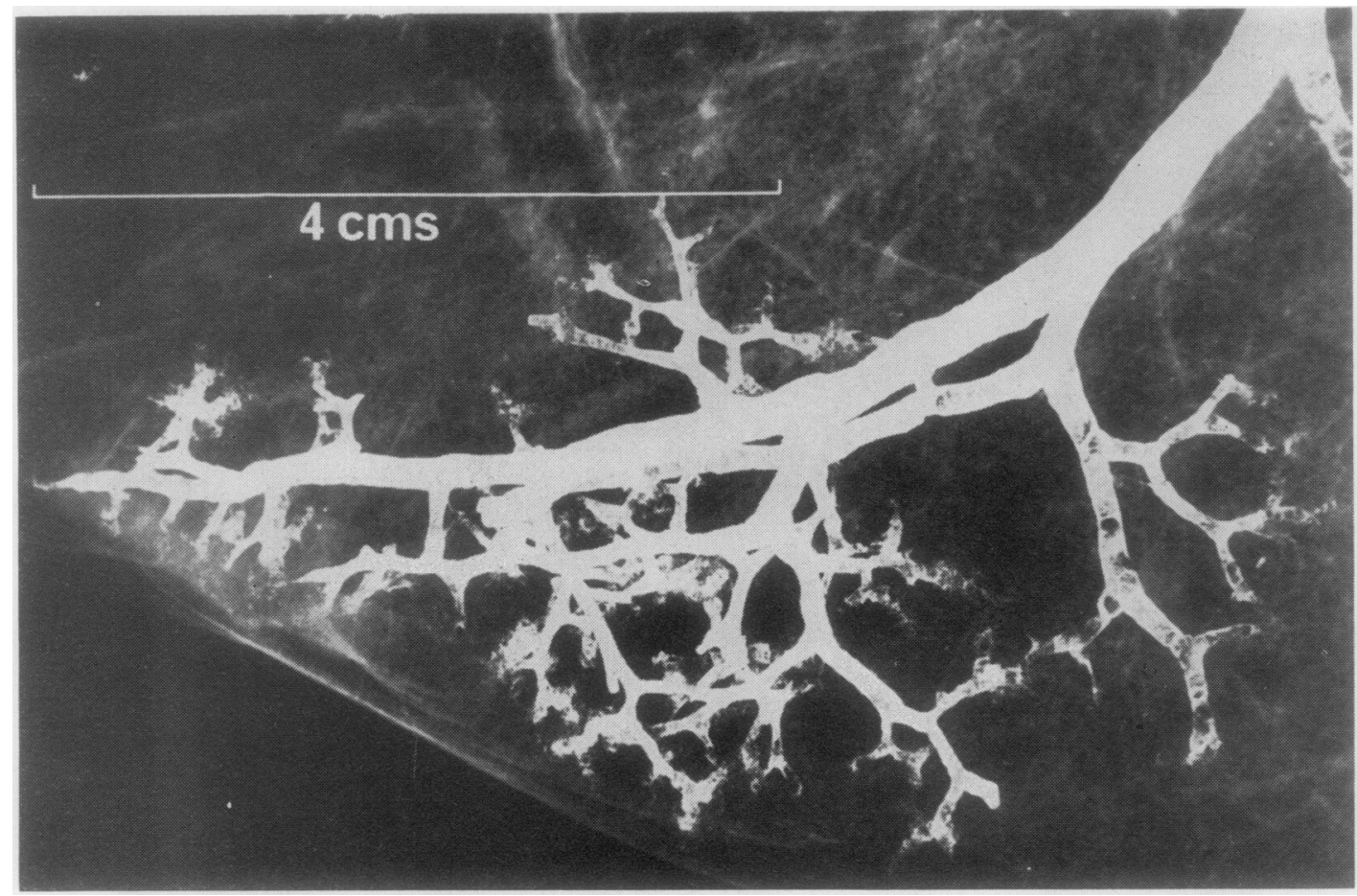

FIG. 4. Case 19. The peripheral $4 \mathrm{~cm}$ of a normal bronchogram. The bronchial walls are smooth and taper gradually, and there is filling down to the smallest bronchioles by tantalum (approximately twice the actual size).

bronchitis has been estimated at $12 \%$ in a general practitioner survey of 1569 patients in the general population (College of General Practitioners, 1961), and the pathological incidence has been found to be $31 \%$ in a necropsy series (Scott, 1973). Emphysema has been found in $74 \%$ of a series of necropsies in London (Heard and Izukawa, 1964), $73 \%$ in Edinburgh (Heard and Hossain, 1970), and $74 \%$ in Glasgow (Roberts and Scott, 1972). Only a small proportion of patients with evidence of chronic airways obstruction, however, die as a result of it. Fletcher (1958) found that deaths attributed to chronic bronchitis amounted to $10 \%$ of all deaths of men between the ages of 45 and 64 years. Patients who die of chronic airways obstruction usually do so following the development of cor pulmonale. This investigation has shown that loss of distal small airways is the part of the disease complex which appears to be most closely related to death in cor pulmonale. Tantalum bronchography is therefore of use in showing the site and extent of the obstruction in chronic airways obstruction but gives little indication as to the nature of the obstruction. From the few cases examined it greater detail histologically it would appear that the obstruction is a mixture of postinflammator $\vec{b}$ fibrosis in the walls of airways with narrowing or complete obstruction of the lumen, as sugo gested by Esterly and Heard (1965) and Bignon. et al. (1969), and mucous plugging of airways, as stressed by McLean (1958). It is not possible using a bronchographic method, to determine whether a bronchus has not filled because of ob? struction of the lumen by pus or because it has been permanently obliterated. The postmortem bronchogram therefore is a good representation of the state of the airways at the time of deathin and the appearances show the combined effects oR acute and chronic disease. However, the changes seen in the bronchial walls, other than obstrucs tion of the lumen, such as irregularity of the walf failure to taper, and areas of narrowing and dilatation, can be considered as indicative of chronic disease.

Acute inflammatory changes in the small air ways are also important, as shown by the fact that histological sections of the lungs from alp 


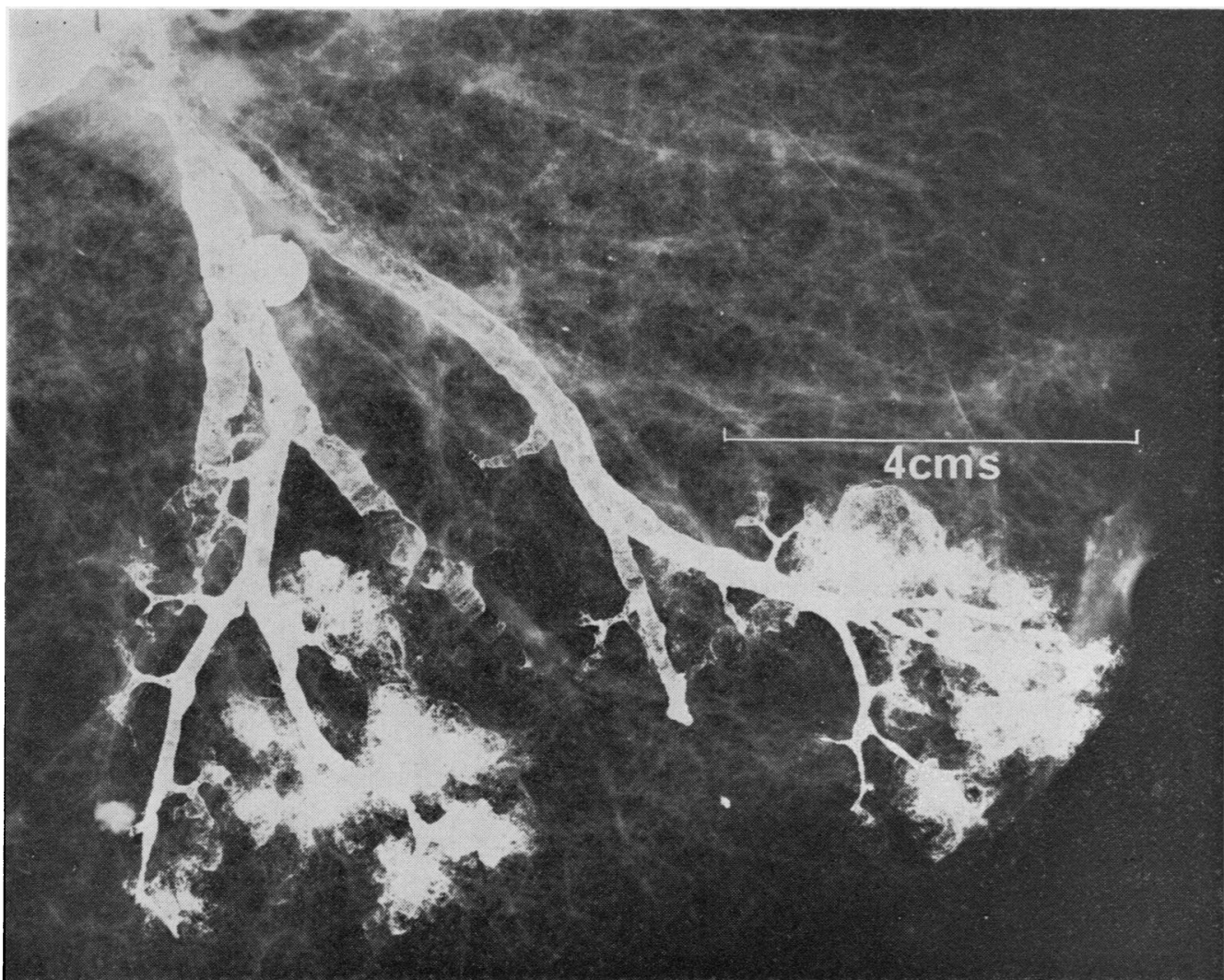

FIG. 5. Case 18. Bronchogram of a lung from a patient with non-fatal respiratory disease. The bronchial walls are irregular and show loss of tapering, and there is some reduction in the number of branches. 'Pooling' of tantalum is also present (actual size).

the patients dying in cor pulmonale showed these changes, but they were present in only half the cases in the non-fatal respiratory disease group and in two out of nine normal cases. These changes were seen in randomly selected blocks from the whole lung and not just from the areas insufflated with tantalum. A more systematic sample from these areas only may have produced slightly different results as acute inflammatory changes could be more severe in one area of the lung than in another, rather than evenly distributed throughout it.

It is possible that small airways are not shown on the bronchograms due to technical problems of filling all the airways with tantalum. The degree of success, approximately $90 \%$, in filling the airways of normal lungs suggests that this is not a very significant factor. Also in the abnormal lungs studied it has been shown that airways which do not fill with tantalum are usually full of mucopurulent secretion.
The accuracy of the bronchographic measurements made in this investigation would appear to be adequate for the sizes of airway diameter involved. Pump (1964) found that the terminal bronchiole varied in diameter between 0.325 and $0.875 \mathrm{~mm}$ and that the respiratory bronchiole varied from 0.131 to $0.875 \mathrm{~mm}$. These diameters vary with the degree of inflation of the lung (Hughes, Hoppin, and Wilson, 1972). An attempt was made to overcome the latter problem by maximally inflating the lung and taking radiographs when it was in a steady state. By using long focus film distances of between 100 and $200 \mathrm{~cm}$ the possible magnification error, due to the unknown position of the bronchi within the lung, was reduced to a maximum of $15 \%$. It was therefore decided not to use the very accurate, but cumbersome tube shift method derived by Hughes et al. (1972). The percentage error in the measurements, using a focal spot with an effective diameter of $1.6 \mathrm{~mm}$ and the focus film distances 


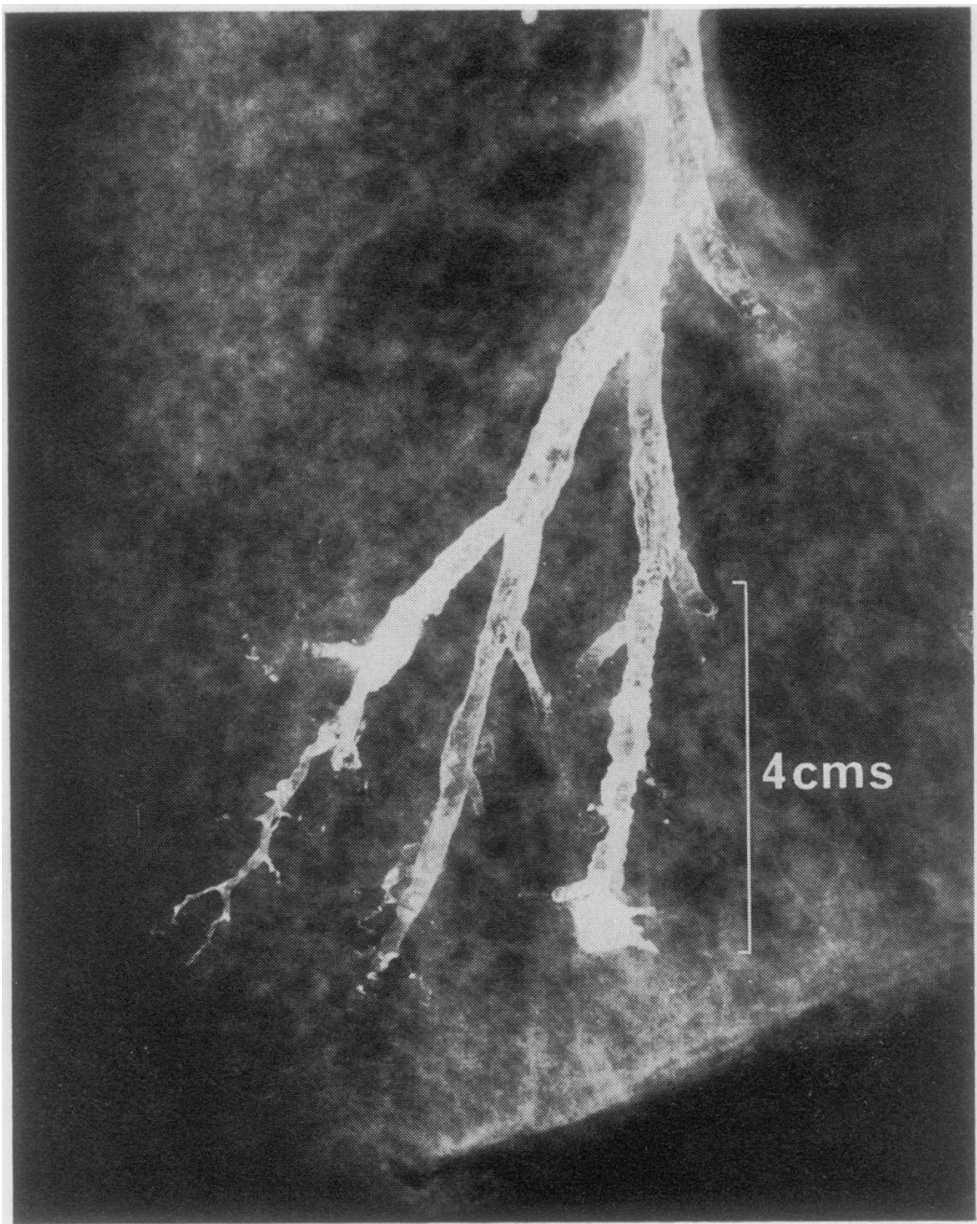

FIG. 6. Case 1. Bronchogram of a lung from a patient dying in cor pulmonale. Bronchial walls are irregular and show areas of dilatation and narrowing, and there is a marked reduction in the number of small airways (actual size).

T A B L E I I DETAILS OF 9 PATIENTS WITH NO CHRONIC RESPIRATORY DISEASE (GROUP I)

\begin{tabular}{|c|c|c|c|c|c|c|c|c|c|}
\hline Case No. & Age & Sex & $\begin{array}{c}\text { No. of Small } \\
\text { Airway } \\
\text { Branches }\end{array}$ & $\begin{array}{c}\text { No. of } \\
\text { Branches } \\
\text { of }<1 \mathrm{~mm}\end{array}$ & $\begin{array}{c}\text { Amount of } \\
\text { Emphysema }\end{array}$ & $\begin{array}{c}\text { Bronchial } \\
\text { Gland Size }\end{array}$ & $\begin{array}{c}\text { Acute } \\
\text { Bronchitis }\end{array}$ & $\begin{array}{c}\text { Right } \\
\text { Ventricular } \\
\text { Weight } \\
\text { (g) }\end{array}$ & Cause of Death \\
\hline $\begin{array}{r}5 \\
6 \\
8 \\
9 \\
14 \\
15 \\
17 \\
19 \\
21\end{array}$ & $\begin{array}{l}66 \\
28 \\
66 \\
73 \\
62 \\
89 \\
54 \\
66 \\
68\end{array}$ & $\begin{array}{l}\mathbf{F} \\
\mathbf{M} \\
\mathbf{M} \\
\mathbf{M} \\
\mathbf{M} \\
\mathbf{F} \\
\mathbf{M} \\
\mathbf{F} \\
\mathbf{F}\end{array}$ & $\begin{array}{l}32 \\
36 \\
60 \\
37 \\
44 \\
20 \\
40 \\
45 \\
22\end{array}$ & $\begin{array}{l}31 \\
26 \\
51 \\
29 \\
30 \\
14 \\
34 \\
42 \\
18\end{array}$ & $\begin{array}{l}0 \\
0 \\
0 \\
2 \cdot 5 \\
0 \\
0 \\
0 \\
5 \cdot 0 \\
5 \cdot 0\end{array}$ & $\begin{array}{r}12 \cdot 0 \\
6 \cdot 0 \\
6 \cdot 1 \\
14 \cdot 5 \\
4 \cdot 7 \\
11 \cdot 3 \\
11 \cdot 4 \\
14 \cdot 6 \\
6 \cdot 8\end{array}$ & $\begin{array}{l}\overline{+} \\
\overline{-} \\
\overline{-} \\
\overline{-} \\
\overline{+}\end{array}$ & $\begin{array}{l}\frac{48}{90}(\mathrm{BVH}) \\
\frac{6}{60} \\
32 \\
110(\mathrm{BVH}) \\
43 \\
-\end{array}$ & $\begin{array}{l}\text { Pulmonary embolus } \\
\text { Cerebral tumour } \\
\text { Pulmonary embolism } \\
\text { Left ventricular failure } \\
\text { Carcinomatosis } \\
\text { Myocardial infarction } \\
\text { Myocardial infarction } \\
\text { Pancreatitis } \\
\text { Pulmonary embolus }\end{array}$ \\
\hline Mean & & & $37 \cdot 4$ & 30.5 & $1 \cdot 4$ & $9 \cdot 7$ & & $63 \cdot 8$ & \\
\hline SE & & & $4 \cdot 1$ & $3 \cdot 8$ & 0.73 & $1 \cdot 2$ & & $12 \cdot 2$ & \\
\hline
\end{tabular}


T A B L E I I I

DETAILS OF 7 PATIENTS DYING IN COR PULMONALE (GROUP 2)

\begin{tabular}{|c|c|c|c|c|c|c|c|c|}
\hline Case No. & Age & Sex & $\begin{array}{c}\text { No. of Small } \\
\text { Airway } \\
\text { Branches }\end{array}$ & $\begin{array}{l}\text { No. of Branches } \\
<1 \mathrm{~mm}\end{array}$ & $\begin{array}{c}\text { Amount of } \\
\text { Emphysema }\end{array}$ & $\begin{array}{c}\text { Bronchial } \\
\text { Gland Size }\end{array}$ & $\begin{array}{l}\text { Acute } \\
\text { Bronchitis }\end{array}$ & $\underset{\text { (g) }}{\text { Right Ventricular Weight }}$ \\
\hline $\begin{array}{r}1 \\
4 \\
7 \\
10 \\
11 \\
12 \\
13 \\
\end{array}$ & $\begin{array}{l}60 \\
44 \\
51 \\
61 \\
66 \\
64 \\
64\end{array}$ & $\begin{array}{l}\mathbf{M} \\
\mathbf{F} \\
\mathbf{M} \\
\mathbf{M} \\
\mathbf{M} \\
\mathbf{M} \\
\mathbf{M}\end{array}$ & $\begin{array}{l}10 \\
24 \\
11 \\
10 \\
16 \\
17 \\
18\end{array}$ & $\begin{array}{r}6 \\
18 \\
8 \\
2 \\
15 \\
12 \\
15\end{array}$ & $\begin{array}{l}48 \\
13 \\
64 \\
45 \\
28 \\
64 \\
45\end{array}$ & $\begin{array}{l}21 \cdot 8 \\
19.6 \\
14.1 \\
19.7 \\
15.6 \\
20.1 \\
14.0\end{array}$ & $\begin{array}{l}+ \\
+ \\
+ \\
+ \\
+ \\
+ \\
+\end{array}$ & $\begin{array}{r}60 \\
135 \\
152 \\
160 \\
140 \\
55 \\
110\end{array}$ \\
\hline Mean & & & $15 \cdot 1$ & $10 \cdot 8$ & $43 \cdot 9$ & $17 \cdot 8$ & & 116.0 \\
\hline SE & & & $2 \cdot 0$ & $2 \cdot 2$ & 6.9 & $1 \cdot 2$ & & $16 \cdot 2$ \\
\hline
\end{tabular}

T A B L E I V

DETAILS OF 6 PATIENTS WITH NON-FATAL CHRONIC RESPIRATORY DISEASE (GROUP 3)

\begin{tabular}{|c|c|c|c|c|c|c|c|c|c|}
\hline Case No. & Age & Sex & $\begin{array}{c}\text { No. of Small } \\
\text { Airway } \\
\text { Branches }\end{array}$ & $\begin{array}{c}\text { No. of } \\
\text { Branches } \\
\text { of }<1 \mathrm{~mm}\end{array}$ & $\begin{array}{c}\text { Amount of } \\
\text { Emphysema }\end{array}$ & $\begin{array}{c}\text { Bronchial } \\
\text { Gland Size } \\
\%\end{array}$ & $\begin{array}{c}\text { Acute } \\
\text { Bronchitis }\end{array}$ & $\begin{array}{l}\text { Right } \\
\text { Ventricular } \\
\text { Weight } \\
\text { (g) }\end{array}$ & Cause of Death \\
\hline $\begin{array}{r}2 \\
3 \\
16 \\
18 \\
20 \\
22\end{array}$ & $\begin{array}{l}66 \\
72 \\
74 \\
78 \\
53 \\
54\end{array}$ & $\begin{array}{l}\mathbf{M} \\
\mathbf{M} \\
\mathbf{M} \\
\mathbf{M} \\
\mathbf{M} \\
\mathbf{M}\end{array}$ & $\begin{array}{l}37 \\
44 \\
24 \\
17 \\
39 \\
33\end{array}$ & $\begin{array}{l}35 \\
39 \\
18 \\
12 \\
35 \\
30\end{array}$ & $\begin{array}{r}27 \\
24 \\
11 \\
41 \\
45 \\
0\end{array}$ & $\begin{array}{r}16 \cdot 0 \\
20 \cdot 5 \\
6 \cdot 4 \\
17 \cdot 5 \\
15 \cdot 4 \\
25 \cdot 3\end{array}$ & $\begin{array}{l}+ \\
\pm \\
- \\
+\end{array}$ & $\begin{array}{r}44 \\
40 \\
43 \\
48 \\
57 \\
130 \text { (BVH) }\end{array}$ & $\begin{array}{l}\text { Bronchopneumonia } \\
\text { Pulmonary embolus } \\
\text { Cirrhosis } \\
\text { Peritonitis } \\
\text { Myocardial infarction } \\
\text { Pulmonary embolus }\end{array}$ \\
\hline Mean & & & $32 \cdot 3$ & $28 \cdot 2$ & $24 \cdot 6$ & $16 \cdot 8$ & & $60 \cdot 3$ & \\
\hline SE & & & $7 \cdot 2$ & $4 \cdot 4$ & $7 \cdot 0$ & $2 \cdot 7$ & & $14 \cdot 1$ & \\
\hline
\end{tabular}

mentioned above, was approximately $20 \%$. The total possible error in the measurement was therefore approximately $35 \%$. The small airways which were not outlined in the severely diseased lungs were mainly in the range of less than $1 \mathrm{~mm}$ in diameter, that is, terminal and respiratory bronchioles. This is in agreement with the findings, by histological methods, of Matsuba and Thurlbeck (1972), who showed that the main deficit in airways of emphysematous lungs was in the range $0.4-0.6 \mathrm{~mm}$ in diameter.

We wish to thank Drs. P. Howard and P. B. Anderson for the clinical data and helpful advice, and $\mathrm{Mr}$. J. Bamforth, Mr. W. De La Haye, and the staff of the Radiology Department of the Royal Hospital, Sheffield, for technical assistance.

\section{REFERENCES}

Bignon, J., Khoury, F., Even, P., Andre, J., and Brouet, G. (1969). Morphometric study in chronic obstructive bronchopulmonary disease. American Review of Respiratory Disease, 99, 669.

College of General Practitioners (1961). Chronic bronchitis in Great Britain. A national survey carried out by the respiratory diseases study group of the College of General Practitioners. British Medical Journal, 2, 973.
Dunnill, M. S. (1962). Quantitative methods in the study of pulmonary pathology. Thorax, 17, 320.

(1968). Quantitative methods in histology. In Recent Advances in Clinical Pathology, Series 5, edited by S. C. Dyke, p. 405. J. and A. Churchill, London.

—, Massarella G. R., and Andersen, J. A. (1969) A comparison of the quantitative anatomy of the bronchi in normal subjects, in status asthmaticus, in chronic bronchitis, and in emphysema. Thorax, 24, 176

Esterly, J. R. and Heard, B. E. (1965). Multiple bronchiolar stenosis in a patient with generalized airways obstruction. Thorax, 20, 309.

Fletcher, C. M. (1958). Disability and mortality from chronic bronchitis in relation to dust exposure. Archives of Industrial Health, 18, 368.

Fraser, R. G. and Paré, J. A. P. (1970). Diagnosis of Diseases of the Chest, p. 994. W. B. Saunders, Philadelphia.

Fulton, R. M., Hutchinson, E. C., and Morgan Jones, A. (1952). Ventricular weight in cardiac hypertrophy. British Heart Journal, 14, 413.

Gamsu, G., Thurlbeck, W. M., Macklam, P. T., and Fraser, R. G. (1971). Peripheral bronchographic morphology in the normal human lung. Investigative Radiology, 6, 161.

Gandevia, B. (1963). The spirogram of gross expiratory tracheobronchial collapse in emphysema. Quarterly Journal of Medicine, 32, 23. 
Heard, B. E. (1958). A pathological study of emphysema of the lungs with chronic bronchitis. Thorax, 13, 136. and Hossain, S. (1970). Emphysema in Edinburgh. Pathologia et Microbiologia, 35, 167. and Izukawa, T. (1964). Pulmonary emphysema in fifty consecutive male necropsies in London. Journal of Pathology and Bacteriology, 88, 423.

Hogg, J. C., Macklem, P. T., and Thurlbeck, W. M. (1968). Site and nature of airway obstruction in chronic obstructive lung disease. New England Journal of Medicine, 278, 1355.

Hughes, J. M. B. Hoppin, F. G., and Wilson, A. G. (1972). Use of stereoscopic X-ray pairs for measurement of airway length and diameter in situ. British Journal of Radiology, 45, 477.

Leopold, J. G. and Gough, J. (1963). Post-mortem bronchography in the study of bronchitis and emphysema. Thorax, 18, 172.

Macklem, P. T., Fraser, R. G., and Brown, W. G. (1965). Bronchial pressure measurements in emphysema and bronchitis. Journal of Clinical Investigation, 44, 897.

McLean, K. H. (1958). The pathogenesis of pulmonary emphysema. American Journal of Medicine, 25, 62 .
Matsuba, K. and Thurlbeck, W. M. (1972). The number and dimensions of small airways in emphysematous lungs. American Journal of Pathology, 67, 265.

Nadel, J. A., Wolfe, W. G., and Graf, P. D. (1968) Powdered tantalum as a medium for bronchos graphy in canine and human lungs. Investigative Radiology, 3, 229.

Pump, K. K. (1964). The morphology of the finer $\overrightarrow{0}$ branches of the bronchial tree of the humanlung. Diseases of the Chest, 46, 379.

Restrepo, G. and Heard, B. E. (1963). The size of the bronchial glands in chronic bronchitis. Journal of $\vec{x}$ Pathology and Bacteriology, 85, 305.

Roberts, G. H. and Scott, K. W. M. (1972). necropsy study of pulmonary emphysema in Glas gow. Thorax, 27, 28.

Scott, K. W. M. (1973). An autopsy study of bronchiab mucous gland hypertrophy in Glasgow. American Review of Respiratory Disease, 107, 239.

Requests for reprints to: Dr. K. W. M. Scott, Depart-ment of Pathology, The University of Sheffield, Beecke Hill Road, Sheffield S10. 